症例

腸間膜静脈血栓症により広範囲回腸壊死をきたした 1 例

\author{
木沢記念病院外科, 岐阜大学第 1 外科 ${ }^{*}$ \\ 山内希美山内
}

脳出血にて加療中に腸間膜静脈血栓症による広範囲回腸壊死をきたした1例を経験し た. 症例は 72 藏, 女性. 主訴は腹部圧痛, 下血。1997 年10月16日, 発語ができず, 脳 出血, 脳室内穿破と診断された. 1998 年 2 月 2 日より下血が認められ，内視鏡にて上下 部消化管に異常を認めず保存的治療を施行していたが, 血圧低下をきたし, 腹部に圧痛 および筋性防御が出現したため 2 月 6 日に外科へ稆介となった. エコーガイド下に腹腔 内穿刺を施行したところ混濁した血性腹水を認めたため, 消化管穿孔と診断し㗨急開腹

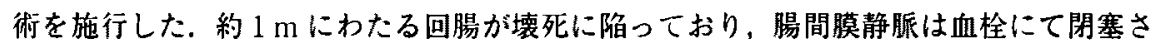
れていた，壊死小腸を切除した，腸管が虚血状態となると梗塞や壊死に宿り，下血は腸 管の強い浮腫や壊死を示唆している、また腸管が壊死に宿った場合の予後は不良とされ ている，血管病変を合併した急性腹症は本症も念頭に入れ，早期診断治療にあたること が重要と思われた。

索引用語：上腸間膜静脈血栓症, 小腸壊死

\section{緒言}

近年, 人口の高齢化に伴い，高齢者の急性腹症を取 り扱う機会も增加している。 上腸間膜血栓症は比較的 稀な疾患とされ，特に高龄者では特異的な症状にそし く術前診断が困難であり，また術後も再発率が高く， 予後不良の疾患の 1 つされている. 今回われわれは 脳出血にて入院加療中に腸間膜静脈血栓症による広範 囲回腸壊死を併発した症例に対し救命し得た 1 例を経 験したので若干の文献的考察を加えて報告する.

\section{症 例}

症例：72 歳, 女性.

主訴：腹部圧痛, 下血.

既往歴：高血圧、糖尿病。

現病歴：1997年 10 月 16 日, 朝起床時に開眼してい るも発語できない状態であるのを家人に発見され，救 急車にて当院へ搬送された.頭部 CTにて脳出血，脳室 内穿破と診断气れ脳外科入入院し保存的加療をうけた ところ, 掑食は可能となったが, 右片麻㾝および運動 性失語症は残存する状態であった. 1998 年 2 月2日よ り下血が認められ継続するので当院消化器内科を受診 し、内視鏡にて精查するも上部，下部消化管に異常を

1999 年 3 月 2 日受付 1999 年 6 月 29 日採用
諗めなかったため保存的治療を施行していたが，血圧 低下をきたし，腹部に圧痛および筋性防御を認めたた め腹膜炎の診断で 2 月 6 日に外科へ紹介となった。

外科䎐科時現症：血圧 $78 / 50 \mathrm{mmHg}$ (DOA $15 \mu \mathrm{g}$ / $\mathrm{kg} / \mathrm{min}$, DOB $15 \mu \mathrm{g} / \mathrm{kg} / \mathrm{min})$, 脈拍 $122 / \mathrm{min}$, 不整. 体温 $38.7^{\circ} \mathrm{C}$. 顔面は荅白で苦悶状であり, 意識レベルは JCS (Japan Coma Scale) 3 点であり，呼吸は浅く努力 栐であった，腹部はやや膨隆し，全体に压痛と筋性防 御を認め, 腸雑音は聴取できなかった。

外科転科時検查所見：軽度筫血, 低アルブミン血症 を認め, CPK $431 \mathrm{IU} / \mathrm{l}, \mathrm{CRP} 38.26 \mathrm{mg} / \mathrm{dl}$ と異常高值 を認めた(表 1)。

腹部単純 $\mathbf{X}$ 線検查：上腹部に拡張した小腸ガス像 が存在し、 Kerckring foldsの拡大および小腸壁の肥厚 を認めた。また遊離ガス像を認めた（图 1).

腹部 $\mathbf{C T}$ 検査 : 腹腔内には腹水と思わ机る low density area 認め, 大動脈壁に石灰化を認めるものの上 腸間膜静脈には明らかな血栓は認めなかった（図2).

腹腔内の腹水の性状を確認するためにエコーガイド 下に腹腔内弿刺を施行したところやや混濁した血性腹 水を認めたため，腸管穿孔に上る汎発性腹膜炎を強く 疑い緊急開腹術を施行した。

手術所見：1998年 2 月 6 日, 全身麻酔下にて腹部正 
表 1 外科転科時検查所見

\begin{tabular}{|c|c|c|c|}
\hline WBC & $8,500 / \mathrm{mm}^{3}$ & BUN & $31.0 \mathrm{mg} / \mathrm{dl}$ \\
\hline $\mathrm{RBC}$ & $3.36 \times 10^{4} / \mathrm{mm}^{3}$ & $\mathrm{Cr}$ & $0.5 \mathrm{mg} \mathrm{dl}$ \\
\hline $\mathrm{Hb}$ & $10.8 \mathrm{~g} / \mathrm{dl}$ & $\mathrm{Na}$ & $157 \mathrm{mEq} / \mathrm{l}$ \\
\hline $\mathrm{Ht}$ & $32.1 \%$ & $\mathrm{~K}$ & $4.1 \mathrm{mEq} / \mathrm{l}$ \\
\hline Plt & $7.9 \times 10^{4} / \mathrm{mm}^{3}$ & $\mathrm{Cl}$ & $127 \mathrm{mEq} l$ \\
\hline $\mathrm{TP}$ & $3.9 \mathrm{~g} / \mathrm{dl}$ & $\mathrm{Fe}$ & $7 \mu \mathrm{g} / \mathrm{dl}$ \\
\hline Alb & $1.7 \mathrm{~g} / \mathrm{dl}$ & CRP & $38.26 \mathrm{mg} / \mathrm{dl}$ \\
\hline T-Bil & $0.66 \mathrm{mg} / \mathrm{dl}$ & FBS & $141 \mathrm{mg} / \mathrm{dl}$ \\
\hline D-Bil & $0.42 \mathrm{mg} / \mathrm{dl}$ & PT & $12.1 \mathrm{~min}$. \\
\hline GOT & $27 \mathrm{IU} / 1$ & APTT & $23 \mathrm{~min}$. \\
\hline GPT & $20 \mathrm{IU} / 1$ & $40^{\circ}$ o $5 \mathrm{~L}$ Mask & \\
\hline $\mathrm{LDH}$ & $696 \mathrm{IU} 1$ & $\mathrm{Po} 2$ & $63.6 \mathrm{mmHg}$ \\
\hline ALP & $92 \mathrm{IU}$ il & Pco2 & $39.3 \mathrm{mmHg}$ \\
\hline $\mathrm{CHE}$ & $1.462 \mathrm{IU} l$ & $\mathrm{BE}$ & $0.7 \mathrm{mEq} / \mathrm{l}$ \\
\hline $\mathrm{CPK}$ & $431 \mathrm{IU} / I$ & $\mathrm{Hco3}$ & $24.4 \mathrm{mEq} / \mathrm{l}$ \\
\hline
\end{tabular}

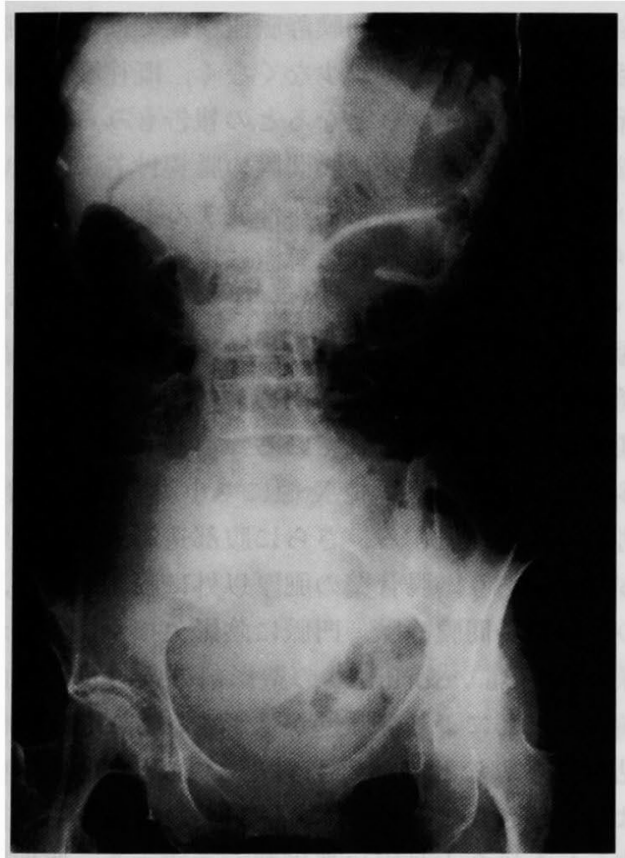

図 1 腹部単純 $\mathrm{X}$ 線検查：上腹部に拡張した小腸ガ ス像が存在し、旅離ガス像を認めた。

中切開にて開腹した. 腹腔内には混濁した血性腹水を 約 $300 \mathrm{ml}$ 認め, 回腸末端より $60 \mathrm{~cm}$ の部位より口側に 約 $1 \mathrm{~m}$ にわたる回腸が壊死に陥っていた，他の腸管に は異常が認められないため壊死腸管を約 $1 \mathrm{~m} 30 \mathrm{~cm}$ 切 除した。また壊死部の腸間膜は著明に肥厚短縮してお り多数の出血斑を認め, 回腸静脈は血栓にて閉塞され た状態にあったが，腸間膜動脈の拍動は触知できた。

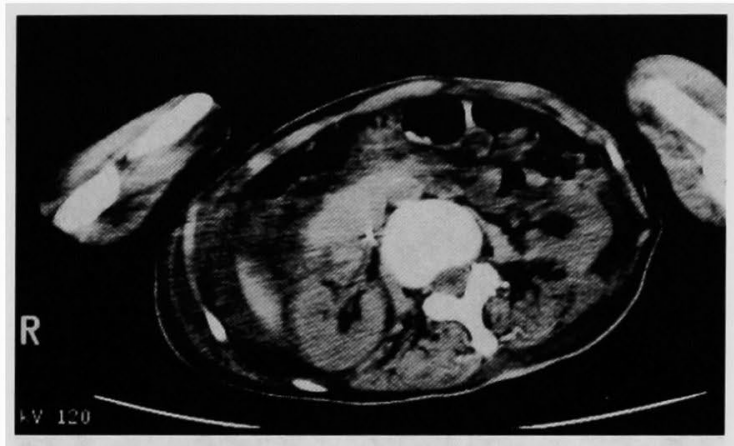

図 2 腹部 CT 検査: 腹水を認め, 大動脈壁に石灰化 を認めるものの上腸間膜静脈に明らかな血栓は認め なかった。

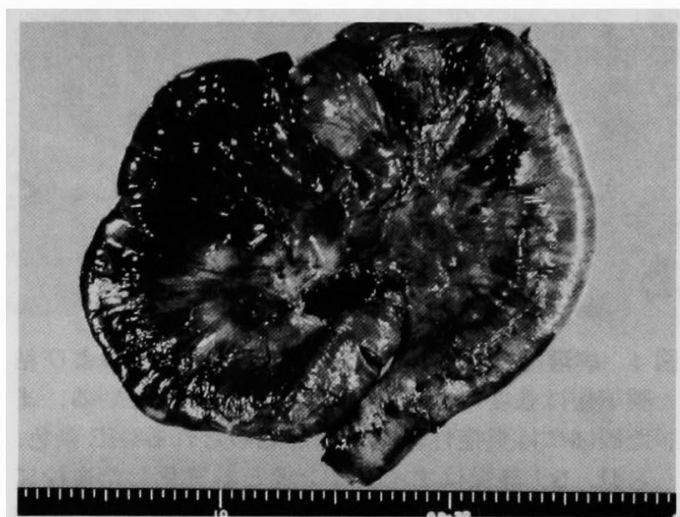

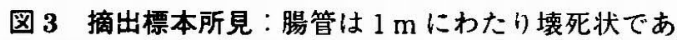
り，非壊死部の腸管も浮腫が著明である。また腸管 膜は肥厚短縮しており, 出血斑を認めた。

摘出標本所見：腸管は $1 \mathrm{~m}$ にわたり壊死状であり, 非壊死部の腸管も浮腫が著明である。また腸間膜は肥 厚短縮しており，出血斑を認めた（図3）。

病理組織学的所見: 静脈血栓が認められた範囲の小 腸壁の粘膜および粘膜下層は強度の浮腫と出血性壊死 に陥っていた (図 $4 \mathbf{a})$ ）腸間膜の静脈内はフィブリン 塊と器質化した血栓がみられ，周囲には炎症性細胞浸 潤が認められる、一方，動脈は壁硬化は認めるものの 開存していた（図 4 b).

術後経過：術直後のエンドトキシンは $36 \mathrm{pg} / \mathrm{ml}$ と 上昇していたため、術直後よりエンドトキシン吸着療 法を施行した。第 6 病日より肺炎を合併したが，保存 的治療により改善でき, 術後 10 力月の現在, 腹部症状 に再発の徵候もなく経過良好である。 


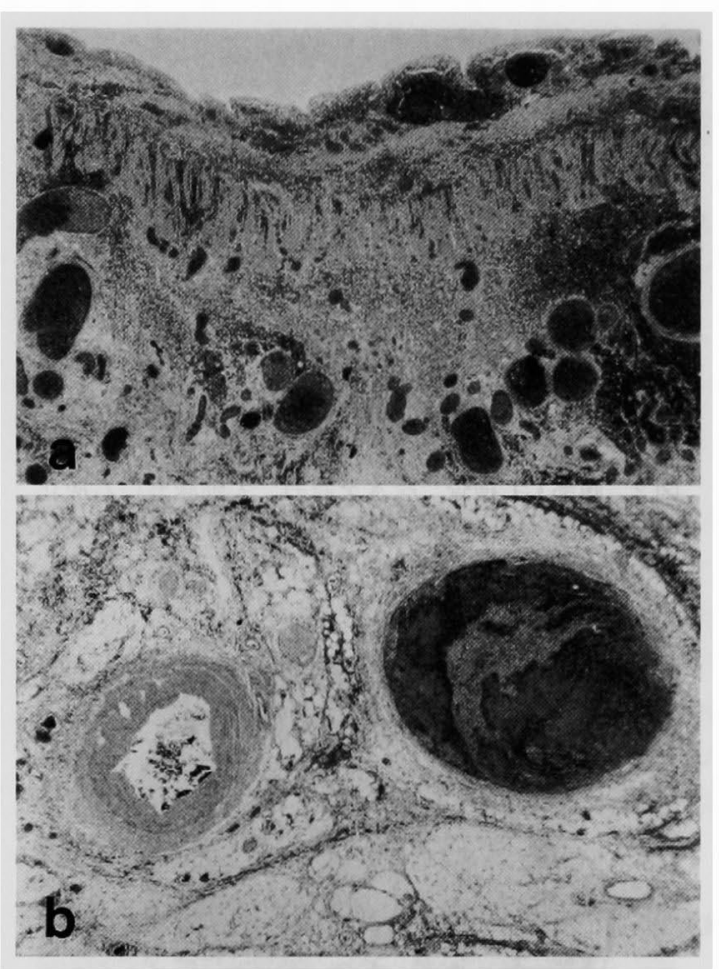

図 4 病理組織学的所見：a：小腸壁の粘膜および粘 膜下層は強度の浮腫と出血性壊死に陥っている。ま た周囲には炎症性細胞浸潤が認められる(HE 染色, ×4). b: 静脈はフィブリン塊と器質化した血栓に て閉塞されており，動脈は壁硬化は認めるものの開 存していた（HE 染色，×4）。

\section{考察}

腸間膜静脈閉塞による腸管壊死は 1895 年 Elliot ${ }^{11}$ に より初回の報告がなされ，本邦では1913 年の藤井”に よるのが最初とされており，われわれの検索では 1997 年までに 110 例の報告がある. 発生頻度は入院患者に おいて手術所見あるいは剖検で確認された症例につい てみると $0.01 \%$ 以下であり，ほとんどは上腸間膜静脈 におこるとされている゙”. 年齢は 18 歳から 82 歳まで 報告され，男性に多い㑯向が認められるいー6).

症状は腹痛, 湢気, 嘔吐,下痢, 下血など非特異的 であり，腸間膜動脈閉塞に認められるような食後の腹 痛はないとされ 囲，下腹部など不定であり，軽度腹痛より始まり、こ のような前駆症状が 5 日から 1 力月程継続し, その後 急激に腹部全体の疼痛に移行するとされている3151. た自騃例にもみられたように心血管系の異常がなくて も血圧低下を認め，便潜血の陽性率は高いのも特徵の
1つと報告されている゙，

上腸間膜静脈血栓症の原因としては特発性と二次性 に分類され，二次性では腹腔内感染症，炎症性疾患， 門脈圧六進症, 腹部外傷, 腹腔内悪性腫瘍, 心疾患, 腎疾患, 妊娠, 血液凝固能異常などがあげられている。 さらにこれら明らかな原因の認められないものが特発 性とされることになるが,こうした特発性の中に何ら かの凝固能異常が関与しているとの報告がみられ る ${ }^{8)}$. 川崎ら”は抗プラスミン剂の投与が上腸間膜静脈 血栓症を苍起したと考えられる症例を報告しており， 特に日本人ではプラスミノーゲン異常症の出現頻度が 高いことより安易に抗ブラスミン剤を投与することは 差し控えるべきであることを強調している. 自験例も 脳出血のため抗プラスミン剂を投与されており線溶系 が抑制されたため血栓形成が促進されたのではないか と推測された。また腸間膜静脈血栓症では末梢静脈血 栓症の既往を有する例が少なくなく、既往歴の問診も 診断上重要な手がかりとなるとの報告もみられる3!。

病態については血栓は腸間膜の腸管付着部に近い分 枝から始まり徐々に中枢側へ伸展すると推測され，閉 塞が本幹におよぶと症状は急激に増悪すると考えられ ている に漏出し血液の濃縮がおこり，血液の缽滞による出血 が槳膜下と粘膜下におこるため, 粘膜と粘膜下の間で 剥離が起こると報告されている゚!.

診断としては腹部単純 X 線にて小腸の拡張を認め, 腸閉塞の所見を呈する.さらに腹部造影 CT は有効と なることがあり，腸管壁の肥厚以外に腸間膜静脈，門 脈の拡張や腸間膜静脈, 門脈に陰影欠損が認められ, 静脈壁の vasa vasorum への造影剂の入った動脈血が 充満することにより静脈壁が造影されるなどと特徽的 所見が得られるとの報告もある5゙. 血管造影は侵襲的 ではあるがさらに有効であり，腸間膜静脈から造影剂 を注入した場合大動脈に造影剂が逆流する，腸間膜動 脈の分枝に㲗縮を認める，腸管壊死に陥った部位への 造影剂の流入がないなどの特徴的所見が得られる. 自 験例は下血が出現してからすでに4 日を経過してお り, 腹膜炎症状を伴い, 昇圧剤を使用するもショック 状態のため単純 CT のみ施行した。画像診断上腸間膜 静脈の血栓は確認できなかったが, 腹水穿刺により血 性腹水を確認したことにより術前に消化管壊死による 腸管穿孔が強く疑われたことより，腹水穿刺は診断に 有効と思われた.

治療は発症から 12 時間以内の早期のものは抗凝固 
殽による保存的治療が有効であるとの報告もある が 治療が主体となることが多い. 全身循環動態を安定さ せた後，買死腸管の切除および術後の抗凝固療法が一 没的とされているが，外科的切除を行っても術後再発 率は高く，本邦では $31 \%$ に再発を認め"”，また再発に よる死亡率は $37 \%$ と報告されており ${ }^{12 !}$ ，術後の再発 予防が予後を決定すると考えられる，再発は吻合部に 多く，一見正常にみえる部位で切離，吻合しても術後 早期に縫合不全をきたすため，健常部を少なくとも 5 〜 $6 \mathrm{~cm}$ を含めて切除すべきであると報告されてい $b^{3)}$.

術後の抗凝固療法については賛否両論があるが，一 般的には施行することが推奖されており，抗凝固療法 が行われた場合の致死率は0\%であるのに対し，行わ ない場合は 50\%の致死率にのほり,術後長期間の十分 交抗凝固療法を施行すべきとの報告もある ${ }^{13}$. 自験例 は腷出血を合併していたため，腸管切除を施行したの みで，術後抗凝固療法は併用せず管理し，再発徵候は 認めていないが、今後も慎重な経過観察が必要と思わ れここに報告した。

\section{結語}

今回われわれは脳出血にて入院加療中に上腸間膜静 豚血栓症にて小腸壊死をきたした症例に対し広籍囲小 腸切除術を施行し，救命した 1 例を経験した。術後に 抗凝固療法の施行が困難なため，正常腸管を含む十分
な小腸切除を施行することにより良好な経過を得るこ とができたので報告した。

\section{文献}

1) Elliot JW : The operative relief of gangrene of the intestine due to occulusion of the mesenteric vessels. Ann Surg 21:9-23.1985

2) 藤井貞治：晹間膜ノ閉塞二因テ起リシ腸塤誼二就 テ. 日外会誌 $15: 104-105,1913$

3）折井正博, 秋山芳伸, 森末 淳他：腸問膜静脈血栓 症. 手術 50:909-915, 1996

4）浦山博, 大竹裕志, 原田 猛他：腸間膜静脈血栓 症. 外科診療 $57: 351-355,1996$

5）川崎富夫, 上林純一：血管. 腸間膜静脈血栓症. 外 科 $57: 1587-1592,1995$

6）成本雅彦, 熊本吉一, 片山清文他：急性腸間膜静脈 血栓症の 1 例. 横浜医 $46: 297-300.1995$

7) Grendell JH. Ockner RK : Mesenteric venous thrombosis. Gastroenterology $82: 358-372,1982$

8）村山英樹：上腸間膜静脈血栓症における血液凝固 線溶系の異常. 医のあゆみ $127: 39-44,1983$

9) Polk HC : Studies in experimental mesenteric venous occlusion. The experimental system and its parameters. Am J Surg 108：693-698. 1964

10）中原数也, 竹谷 弘, 吉网淳二他：特発性腸間膜静 眽閉塞に上る腸壊死の1治雅例. 外科 33 ： 1140-1146. 1971

11）熊谷洋一, 山崎 繁, 三浦則正他：上腸間膜静脈血 栓症の 1 例. 太田病年報 $31: 17-21,1996$

I2) Jona J. Cumminis GM. Head HB, et al : Recurrent primary mesenteric venous thrombosis. JAMA 227: 1033-1035. 1974

13) Natove A. Weismann RE : Primary mesenteric venous thrombosis. Ann Surg $161: 516-523$. 1965

\title{
A CASE OF MESENTERIC VENOUS THROMBOSIS WITH EXTENSIVE SMALL BOWEL NECROSIS
}

\author{
Kimi YAMAUCHI, Hajime YAMAC:CHI and Hiroshi TANABE* \\ Department of Surgery, Kizawa Memorial Hospital \\ -First Department of Surgery. Gifu University School of Medicine
}

A case of mesenteric venous thrombosis causing extensive small bowel necrosis during treatment for cerebral hemorrhage. A 72-year-old woman, who was admitted to the department of internal medicine in our hospital for treatment of intracerebral hemorrhage since October 1997. was referred to the department because of anal bleeding, a significant decrease in blood pressure. abdominal tenderness, and muscle gurding on February 6.1998. Echo-guided puncture of peritoneal fluid confirmed bloody ascites. Emargency operation was performed under a diagnosis of perforation of the small intestine. There existed the necrotic ileum proxi$\mathrm{mal} 60 \mathrm{~cm}$ and distal $160 \mathrm{~cm}$ from the ileocaecal valve was resected and mesenteric venous thrombosis. About $130 \mathrm{~cm}$ of the intestine was resected in determining intestinal viability safety included the necrotized bowel. Anticoagulant therapy, as not given, because of intracerebral hemorrhage. There have been no signs of recurrence as of nine months after the operation. If bowel ischemia occurs, the superior mesenteric vein is commonly involved and the affected bowel becomes edematous and necrotic. So anal bleeding suggests severe edema and necrosis of the intestine, and in this case the prognosis is believed to be poor. We must keep in mind the condition as a probable differential diagnosis for patients manifesting acute abdomen with vascular disease. 